\title{
The Relationship between Income and Material Hardship
}

James X. Sullivan
Lesley Turner
Sheldon Danziger

\begin{abstract}
This paper examines the relationship between income and the extent of material hardship and explores other factors that might affect hardship. Using panel data from the Women's Employment Study, we examine the incidence of material hardship from 1997 to 2003 among current and former welfare recipients. We then consider the extent to which income is associated with hardship. We show that hardship decreases monotonically across quintiles of the income distribution for several income measures. When we measure income as the average across the 6-year study period, a 10 percent increase in average income is associated with a 1.1 percentage point decrease in the likelihood of experiencing a hardship, a drop of about 3.4 percent. We also find that the relationship between transitory changes in income and hardship is weak. These results are consistent with findings based on a nationally representative sample of disadvantaged households from the Survey of Income and Program Participation. Our results indicate that observable factors, such as measures of mental health, are more strongly related to hardship than current income. () 2008 by the Association for Public Policy Analysis and Management.
\end{abstract}

\section{INTRODUCTION}

Policymakers and researchers commonly use income as a proxy for material wellbeing. Policymakers rely on the official poverty measure, based on money income, both to gauge the extent of deprivation and to allocate billions of dollars in federal spending on social welfare programs to needy families (Citro \& Michael, 1995). Means-tested programs designed to prevent material hardship, such as food stamps, ${ }^{1}$ housing assistance, and Medicaid, rely on measures of current income and assets to target benefits at disadvantaged families. Researchers commonly use income as a proxy for material well-being when they analyze trends in poverty and inequality and the antipoverty effects of government programs.

This paper examines the relationship between a variety of income measures and the extent of material hardship and explores other factors that might affect hardship experiences. Using data from the Women's Employment Study (WES), a survey that includes panel data on both income and hardships, we examine the incidence of material hardships from 1997 to 2003 among current and former welfare recipients. We then consider how income is associated with these hardships, distinguishing between

\footnotetext{
${ }^{1}$ An explicit goal of the Food Stamp Program is to alleviate hunger and malnutrition (United States Senate, 2004).
} 
current and long-run measures. The WES also allows us to analyze the relationship between hardship and personal characteristics that are typically not available in household surveys, such as physical health, mental health, and access to credit.

We show that hardship decreases monotonically across quintiles of the income distribution for several income measures. The relationship between average income over the panel and hardship is strong. A 10 percent increase in average income is associated with a 1.1 percentage point decrease in the likelihood of experiencing a hardship_-a drop of about 3.4 percent. We verify that this relationship is not unique to our sample of current and former welfare recipients by analyzing similar data for a sample of less-educated single mothers from the Survey of Income and Program Participation (SIPP).

Holding constant average income over the panel, there is little evidence of an additional relationship between current income and hardship. Individual fixed effects models also indicate that the relationship between transitory income and hardship is weak. We discuss potential explanations for this weak relationship. For example, the permanent income hypothesis suggests that because households can save or borrow to offset transitory income changes, hardships are sensitive to permanent, but not to transitory, changes. However, the weak relationship between transitory income and hardship that we document cannot entirely be explained by the intertemporal substitution of income or the misreporting of transfer income. We suggest that our findings are consistent with ethnographic research that documents that informal, typically unmeasured, resources play an important role in helping the disadvantaged make ends meet.

Characteristics such as having a mental health disorder or not having a checking or savings account are significantly related to hardship, even after controlling for unobserved heterogeneity. They are also better predictors of hardship than is current income. Although we do not interpret our estimates for income or these other factors as causal, our results have important policy implications. They suggest that long-run resources and observable personal attributes can help to target meanstested transfers more effectively at those facing the greatest risk of hardship.

The structure of this paper is as follows: In the next section, we discuss previous research on the relationship between income and material hardship. The following section describes the WES and the SIPP, presents descriptive results, and outlines our methods. We then present empirical results and discuss the relationship between income and hardship. The final section offers conclusions and discusses policy implications.

\section{PREVIOUS RESEARCH ON INCOME AND MATERIAL HARDSHIP}

Families with low income are less able to meet their basic needs and hence are more likely to experience material hardships, defined to represent unfavorable economic circumstances. $^{2}$ Nonetheless, past research finds a weak relationship between income and hardship. Mayer and Jencks (1989), finding that current income explains only 14 percent of the variation in the number of material hardships a family experiences, conclude that income poverty is not a reliable proxy for material hardship. ${ }^{3}$ Similarly, Short (2005) notes that poor families and those experiencing material hardships are distinct groups. ${ }^{4}$

\footnotetext{
${ }^{2}$ For a survey of measures of material hardship and related empirical research, see Ouellette, Burstein, Long, and Beecroft (2004).

${ }^{3}$ Mayer and Jencks (1989) examine measures of food insufficiency, unpaid rent, crowded housing, eviction, having utilities shut off, housing problems, lack of health insurance, and unmet medical or dental needs.

${ }^{4}$ Also, see Beverly (1999), Edin and Lein (1997), and Rector, Johnson, and Youssef (1999).
} 
Long-run income should be more highly correlated with material well-being than current income if families can substitute income intertemporally or if long-run income is measured with less error than current income. Mayer (1997) shows that families with low average income over a 5-year period score about a third of a standard deviation lower on an index of living conditions than families with low current income, ${ }^{5}$ and that average income is a better predictor of child outcomes than current income. ${ }^{6}$ Meyer and Sullivan (2003) show that current consumption is more closely associated with measures of material well-being than is current income and conclude that for disadvantaged families, consumption is better measured than income. Using the 1996 SIPP, Iceland and Bauman (2007) find that poverty spells are associated with hardship, but when they control for a family's average income while not in poverty, the magnitude of this association is reduced. ${ }^{7}$ Mayer and Jencks (1989) find that variation in permanent income does not explain variation in hardship, but their measure of permanent income is an average over just two periods.

This paper extends the existing literature in several ways. First, we analyze panel data that include multiple measures of both income and hardship over a period of 6 years. Previous research relies on cross-sectional data or panels spanning less than 3 years. We distinguish between current and long-run income, and we use fixed effect models to examine how the transitory component of current income, controlling for unobservable characteristics, is related to hardship. Second, we explore how the relationship between income and hardship varies for different income measures, such as money income and disposable income. Third, by matching survey and administrative data on means-tested transfers, we examine the extent to which underreporting of transfer income in surveys might explain the weak relationship between current income and hardship. Last, we incorporate a rich set of observable characteristics not typically available, including mental health, drug use, and access to credit, and find that these characteristics are significant correlates of material hardship.

\section{DATA AND METHODS}

\section{Data}

The Women's Employment Study (WES) sample was systematically selected from the February 1997 caseload of single mother welfare recipients between the ages of 18 and 54 who were either Caucasian or African American and resided in one urban Michigan county. Sample members were interviewed in their homes five times over a period of about 6 years, in the fall of 1997, 1998, 1999, 2001, and 2003. In each wave, respondents provided detailed information on their income in the previous month and previous calendar year, self-reports of a number of material hardships, and a variety of individual and family characteristics. The WES also includes data on mental and physical health, illegal drug use, access to credit, and car and home ownership. The Appendix contains definitions of the variables used in our analyses. ${ }^{8}$

\footnotetext{
${ }^{5}$ Mayer analyzes data from the 1968 to 1972 Panel Study of Income Dynamics. Her living conditions index included information on vehicle and home ownership, food expenditures, health insurance, and whether the house was clean or needed major repairs.

${ }^{6}$ Using data from the National Longitudinal Survey of Youth, Blau (1999) shows that permanent income, measured as average family income from 1979 to 1991, has a larger effect on child outcomes than does current income, but the effect of permanent income is smaller than that of other attributes, including race, gender, or mother's attributes. See Dahl and Lochner (2005) for a summary of this literature.

${ }^{7}$ Other outcomes are weakly related to poverty. For example, Bhattacharya, Currie, and Haider (2004) show that current poverty status has little predictive power for nutritional outcomes among school-age children, but that it is related to nutrition for preschoolers and adults.

${ }^{8}$ All appendices are available at the end of this article as it appears in JPAM online. Go to publisher's Web site and use search engine to locate article at http://www3.interscience.wiley.com/cgi-bin/jhome/34787.
} 
Stacking five waves of data yields an unbalanced panel of 3,191 observations from 753 unique respondents. We restrict the sample to respondents who completed at least three interviews, reducing the sample to 2,978 observations. ${ }^{9}$ Some control variables are not available in all waves. Thus, specifications that include both access to credit (not available in the second wave) and whether the respondent has a checking or savings account (not available in the first wave) include 1,726 observations.

Our measure of disposable income is the sum of after-tax money income, food stamps, and cash transfers from friends and family for all household members. ${ }^{10}$ These income sources are reported by the respondent for the month before the survey. ${ }^{11}$ The amount and receipt of cash assistance and food stamps for each respondent's household was provided to us from administrative records from Michigan's Family Independence Agency and by respondent self-reports. We use the administrative data to determine the extent to which misreporting of transfer income affects the relationship between income and material hardship.

We consider the relationship between hardship and current income and the transitory and permanent components of current income. Current income is used to determine eligibility for means-tested programs for the disadvantaged because it is relatively easy for program administrators to observe. However, permanent income is likely to be a better measure of well-being than current income, because it captures long-run resources and reflects access to credit and the insurance value of government programs. Following several other studies (Blau, 1999; Mayer, 1997; Mayer \& Jencks, 1989), we measure permanent income as average income across all years that a household is in the panel. If all families had perfect access to credit, then we would not expect there to be a relationship between transitory income and hardships that result from a lack of resources. However, because the disadvantaged face borrowing constraints, we examine the relationship between transitory income and hardship to determine whether temporary shortfalls in income are associated with hardship for these current and former welfare recipients.

We focus on four measures of material hardship included in all five survey waves: whether a respondent experienced food insufficiency, whether her utilities were shut off, whether she had been evicted, and whether she had been homeless. The reference period for these hardships is the 12 months before the interview for the first wave and the months between interviews for subsequent waves. We define two summary measures: whether a respondent experienced any of these four hardships and the total number of hardships experienced. We also analyze other hardships reported in fewer waves, including whether a respondent's telephone was disconnected because she was unable to pay the bill, whether she or her children went without proper winter clothing because of cost constraints, and whether she needed to see a doctor or dentist but could not afford to do so.

These hardships are among the most commonly analyzed in previous studies because domestic social policies, including food, housing, medical, and income

\footnotetext{
${ }^{9}$ Attrition in the WES is relatively low for a panel study of this length. The Wave 5 sample size is 71 percent of the Wave 1 sample. There is little difference in mean disposable income or frequency of hardship between attriters and non-attriters at baseline, although the former are slightly younger and less likely to be married. For a discussion of attrition in the WES, see Cadena and Pape (2006).

${ }^{10}$ All income measures are equivalence-scale adjusted for family size and composition using the scale recommended by the National Research Council Panel on Poverty and Family Assistance (Citro \& Michael, 1995): (number of adults + number of children*0.7) ( $^{0.7}$.

${ }^{11}$ WES respondents also report total household income for the previous calendar year. This measure may differ from monthly income if the survey month does not reflect the respondent's typical month for income. However, income in the prior month is based on responses to many questions about specific income sources, whereas the annual measure is based on responses to only two questions regarding total household earnings and total income from all other sources. Monthly income is less susceptible to recall error (Eisenhower, Mathiowetz, \& Morganstein, 1991; Groves, 1989).
} 
support programs, seek to alleviate them (Beverly, 1999, 2001; Mayer \& Jencks, 1989). Nevertheless, they do not capture all possible hardships. Other hardship research has studied lack of consumer durables and poor housing and neighborhood conditions. There is little consensus in this literature on the most appropriate measures of hardship, and most measures suffer to some extent by the fact that variation in hardships may partly reflect heterogeneity in preferences rather than differences in material well-being (Ouellette, Burstein, Long, \& Beecroft, 2004).

Although all WES respondents were residents of a single county, their characteristics are quite similar to those of disadvantaged mothers from nationally representative samples. Trends in the receipt of cash assistance and employment for WES respondents are comparable to those in a sample of current and former welfare recipients in the SIPP (Seefeldt \& Orzol, 2005). Furthermore, the macroeconomic conditions and nature of welfare reforms to which WES respondents were exposed were similar to those in other states that contained a majority of the Temporary Assistance to Needy Families (TANF) caseload in 1997 (Turner, Danziger, \& Seefeldt, 2006).

To determine the extent to which WES results are generalizable, we analyze the relationship between income and hardship in the 1996 Panel of the SIPP, a nationally representative panel that interviews households at 4-month intervals for a period of up to 4 years. Although the SIPP collects detailed income information at each wave, respondents are only asked about material hardship at one wave. We examine several samples of disadvantaged households from the SIPP including less-educated single mothers and households below the poverty line. The Appendix provides a description of income and hardship variables in the SIPP. ${ }^{12}$

\section{Descriptive Results}

The summary statistics in Table 1 demonstrate that WES respondents are economically disadvantaged. ${ }^{13}$ At a typical interview, nearly one-third had experienced at least one of the four material hardships since the previous interview. Mean disposable income adjusted for family size, $\$ 18,624$ in 2003 dollars, was approximately 125 percent of the poverty line. ${ }^{14}$ More than one-quarter did not have a GED or high school diploma, nearly a quarter reported having poor health, and 29 percent met the diagnostic screening criteria for one of the three mental health disorders that were evaluated at all waves.

As shown in columns 2 and 3 of Table 1, respondents who reported experiencing any of the four hardships had significantly lower mean annualized money income or mean disposable income than those who did not experience a hardship. The former also were less educated, more likely to have met the diagnostic screening criteria for a mental health problem, to have poor health status, and to have used drugs, and were less likely to be married, to own a car or home, or have access to credit.

Experiences of food insufficiency and having utilities shut off, 22 and 10 percent, respectively, were similar to those reported by Mayer and Jencks (1989) from a survey of Chicago residents that oversampled poor families. Eviction, at 8 percent, was more prevalent than in the Mayer and Jencks study. ${ }^{15}$

\footnotetext{
${ }^{12}$ All appendices are available at the end of this article as it appears in JPAM online. Go to publisher's Web site and use search engine to locate article at http://www3.interscience.wiley.com/cgi-bin/jhome/34787.

${ }^{13}$ Disadvantaged households are the appropriate group for examining the relationship between income and hardship, because material hardship is very rare for households with significant resources. For example, only about 0.6 percent of those in the top two quintiles of the disposable income distribution for all households in the 1996 SIPP report being food insufficient, having utilities shut off, or being evicted. ${ }^{14}$ We calculate this statistic using the official poverty line for a family with one adult and two children in $2003(\$ 14,824)$.

${ }^{15}$ Mayer and Jencks report rates of food insufficiency, utilities shut off, and eviction of 22.4 percent, 7.4 percent, and 1.0 percent, respectively. Also, see hardship rates reported by Boushey and Gundersen (2001), Iceland and Bauman (2007), and Ouellette et al. (2004).
} 
Table 1. Descriptive statistics.

\begin{tabular}{|c|c|c|c|}
\hline & $\begin{array}{l}\text { All } \\
\text { (1) }\end{array}$ & $\begin{array}{l}\text { Any Hardship } \\
\text { (out of } 4) \\
\text { (2) }\end{array}$ & $\begin{array}{l}\text { No Hardship } \\
\text { (out of 4) } \\
\text { (3) }\end{array}$ \\
\hline \multicolumn{4}{|l|}{ Hardships } \\
\hline Any Hardship (out of 4) & 0.32 & 1.00 & 0.00 \\
\hline Number of Hardships (out of 4) & 0.44 & 1.35 & 0.00 \\
\hline Food Insufficiency & 0.22 & 0.66 & 0.00 \\
\hline Utilities Shut Off & 0.10 & 0.30 & 0.00 \\
\hline Evicted & 0.08 & 0.24 & 0.00 \\
\hline Homeless & 0.05 & 0.15 & 0.00 \\
\hline \multicolumn{4}{|l|}{ Other Hardships } \\
\hline Phone Shut Off $(\mathrm{N}=1719)$ & 0.31 & 0.58 & 0.19 \\
\hline Can't Afford Clothing $(\mathrm{N}=1719)$ & 0.10 & 0.24 & 0.04 \\
\hline \multicolumn{4}{|l|}{ Income Measures } \\
\hline Disposable Income & $\$ 18,624$ & $\$ 16,171$ & $\$ 19,800 * *$ \\
\hline Money Income & 12,549 & 9,950 & $13,795 * *$ \\
\hline \multicolumn{4}{|l|}{ Family Characteristics } \\
\hline Age & 32.5 & 32.5 & 32.5 \\
\hline Race $=$ African American & 0.55 & 0.55 & 0.55 \\
\hline Less Than High School Diploma & 0.27 & 0.38 & $0.22 * *$ \\
\hline High School Graduate/GED & 0.38 & 0.36 & 0.38 \\
\hline Greater Than High School & 0.35 & 0.26 & $0.40 * *$ \\
\hline Number of Children in Household & 2.35 & 2.45 & $2.30 * *$ \\
\hline Any Mental Health Disorder & 0.29 & 0.43 & $0.22 * *$ \\
\hline Any Drug Use & 0.17 & 0.25 & $0.13 * *$ \\
\hline Married & 0.16 & 0.11 & $0.18 * *$ \\
\hline Cohabiting & 0.19 & 0.18 & 0.19 \\
\hline Not Married or Cohabiting & 0.66 & 0.72 & $0.63 * *$ \\
\hline Employed & 0.65 & 0.56 & $0.68 * *$ \\
\hline Poor Health & 0.23 & 0.31 & $0.19 * *$ \\
\hline Owns Car & 0.78 & 0.66 & $0.83 * *$ \\
\hline Owns Home & 0.24 & 0.17 & $0.28 * *$ \\
\hline Access to Credit $(N=1725)$ & 0.74 & 0.60 & $0.80 * *$ \\
\hline Checking/Saving Account $(N=1721)$ & 0.67 & 0.54 & $0.73 * *$ \\
\hline Observations & 2,978 & 965 & 2,013 \\
\hline
\end{tabular}

Source: Women's Employment Study (WES), Wave 1-Wave 5, 1997-2003.

Notes: $* p<0.05, * * p<0.01$ denote significance of a test of the difference in means between columns 2 and 3. All income values are reported in constant 2003 dollars and are adjusted for family size, standardized to a family with one adult and two children. Noted differences in sample size are due to missing values for some variables. See the Appendix online for more details.

Comparisons of the WES sample to a sample of female welfare recipients from the 1996 SIPP panel reveal some differences (tables available from the authors). The SIPP sample is slightly older, less educated, and significantly less likely to be employed, and disposable income is about 8 percent lower than that of the WES sample. Reports of hardship are significantly lower in the SIPP, which is, in part, because of the shorter SIPP reference period for some hardships (the previous 4 months).

As shown in Table 2, experiences of material hardship for WES respondents fell following welfare reform and during the economic boom of the late 1990s, with 38 percent experiencing hardship in 1997 and 27 percent in 2001. Hardship increased after the recession, reaching 31 percent in 2003. The decrease in food insufficiency from 25 to 19 percent over the 6 years accounts for most of the decline in any hardship. 
Table 2. Trends in hardship and income.

\begin{tabular}{|c|c|c|c|c|c|c|}
\hline & 1997 & 1998 & 1999 & 2001 & 2003 & Change \\
\hline Hardship Measures & & & & & & $2003-1997$ \\
\hline $\begin{array}{l}\text { Any Hardship } \\
\text { (out of } 4 \text { ) }\end{array}$ & 0.375 & 0.330 & 0.329 & 0.268 & 0.311 & -0.064 \\
\hline $\begin{array}{l}\text { Number of Hardships } \\
\text { (out of } 4 \text { ) }\end{array}$ & 0.506 & 0.444 & 0.442 & 0.363 & 0.431 & -0.075 \\
\hline Food Insufficiency & 0.251 & 0.229 & 0.230 & 0.170 & 0.187 & -0.064 \\
\hline Utilities Shut Off & 0.092 & 0.103 & 0.089 & 0.081 & 0.118 & 0.026 \\
\hline Evicted & 0.091 & 0.074 & 0.081 & 0.075 & 0.067 & -0.023 \\
\hline Homeless & 0.072 & 0.037 & 0.042 & 0.037 & 0.058 & -0.013 \\
\hline Income Measures & & & & & & $2003 / 1997$ \\
\hline Disposable Income & $\$ 15,300$ & $\$ 17,002$ & $\$ 18,503$ & $\$ 19,738$ & $\$ 20,259$ & 1.324 \\
\hline Food Stamps & $\$ 2,127$ & $\$ 1,736$ & $\$ 1,252$ & $\$ 1,308$ & $\$ 1,373$ & 0.646 \\
\hline $\begin{array}{l}\text { Cash Welfare } \\
\text { (TANF) }\end{array}$ & $\$ 2,889$ & $\$ 1,502$ & $\$ 949$ & $\$ 912$ & $\$ 747$ & 0.259 \\
\hline Earnings & $\$ 5,559$ & $\$ 7,198$ & $\$ 8,156$ & $\$ 8,808$ & $\$ 8,813$ & 1.585 \\
\hline Money Income & $\$ 10,167$ & $\$ 9,894$ & $\$ 12,859$ & $\$ 15,118$ & $\$ 15,189$ & 1.494 \\
\hline Observations & 629 & 619 & 626 & 570 & 534 & \\
\hline
\end{tabular}

Source: WES, 1997-2003.

Notes: See notes to Table 1.

Average annualized disposable income increased by 32 percent in real terms over the period, from $\$ 15,300$ to $\$ 20,259$, consistent with trends near the bottom of the distribution for a nationally representative sample of single mothers (Meyer \& Sullivan, 2006). Trends in income differ substantially by income source. Cash welfare and food stamp receipt dropped sharply, whereas average earnings increased by 59 percent. Consequently, measures excluding food stamps, such as money income, grow at a faster rate than disposable income ( 49 vs. 32 percent).

Figure 1 shows that hardship decreases monotonically across quintiles of the distributions of current disposable income, current money income, and disposable income averaged over three to five survey waves. The incidence of any hardship is 18 percent higher in the bottom quintile of current disposable income than in the second quintile (45 vs. 38 percent). ${ }^{16}$ This difference is sizable given the relatively narrow income range in this sample-disposable income at the 20th and 40th percentiles differs by less than $\$ 4,000$.

Hardships also fall across quintiles of current money income, although the decline is not significant between all quintiles - there is little difference in hardship between the second and third quintiles, for example. Differences in the incidence of hardship are most evident when comparing households across quintiles of the distribution of average disposable income. The incidence of any hardship is about 25 percent higher in the bottom quintile than in the second quintile ( $47 \mathrm{vs.} 38$ percent).

The incidence of specific hardships is likewise decreasing in current disposable income (Figure 2). Food insufficiency is 22 percent higher in the bottom quintile than in the second quintile (31 vs. 25 percent), and it is about twice as high in the bottom quintile as in the top. Homelessness is about twice as high in the bottom

${ }^{16}$ In results not shown, we find that hardship decreases across the income distribution for all SIPP households. The correlation coefficients for income and hardship in the WES are smaller than those of Mayer and Jencks (1989), but consistent with those in Short (2005), Federman et al. (1996), Beverly (2000), and Boushey and Gundersen (2001). These results are available from the authors. 


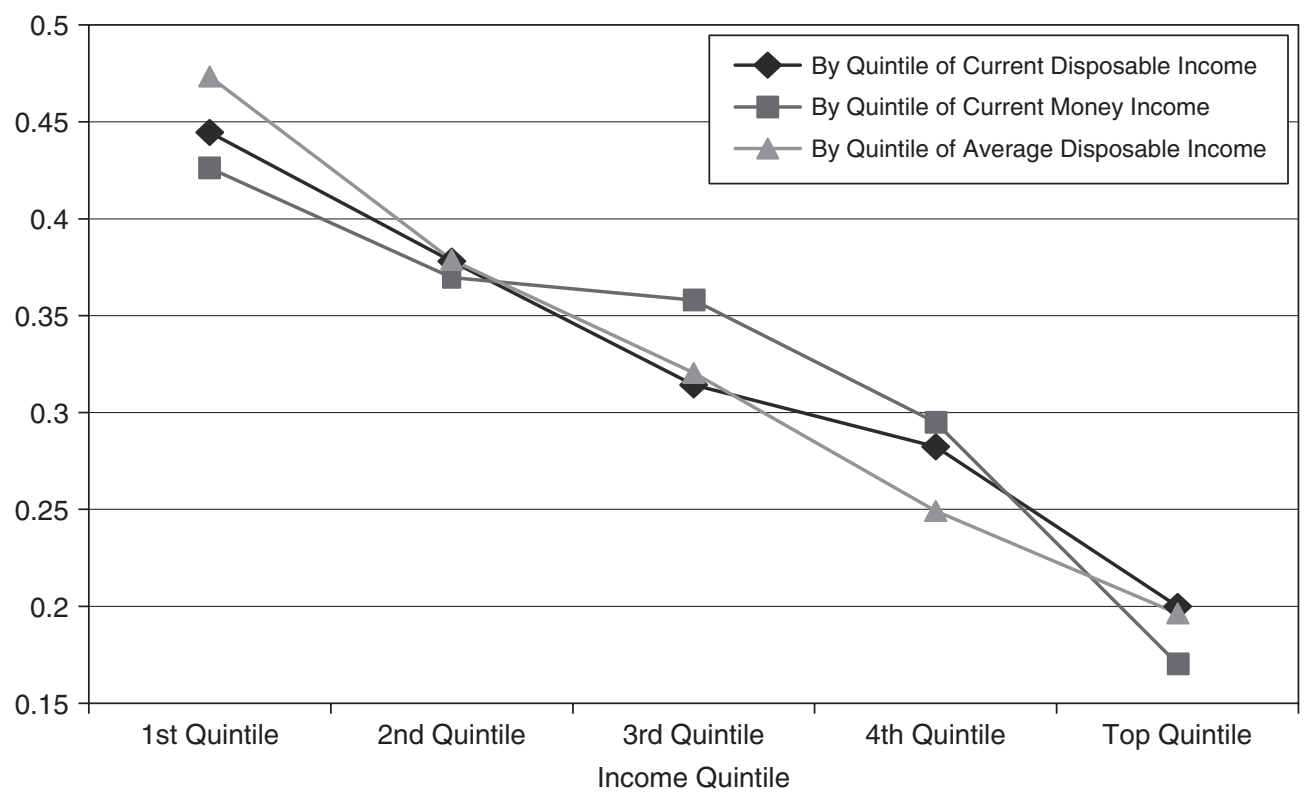

Source: Women's Employment Study (WES), Wave 1-Wave 5, 1997-2003.

Notes: Hardships include: food insufficiency, utilities shut off, eviction, and homelessness. See the Appendix online for more details.

Figure 1. Fraction experiencing at least one of four hardships by quintile of income.

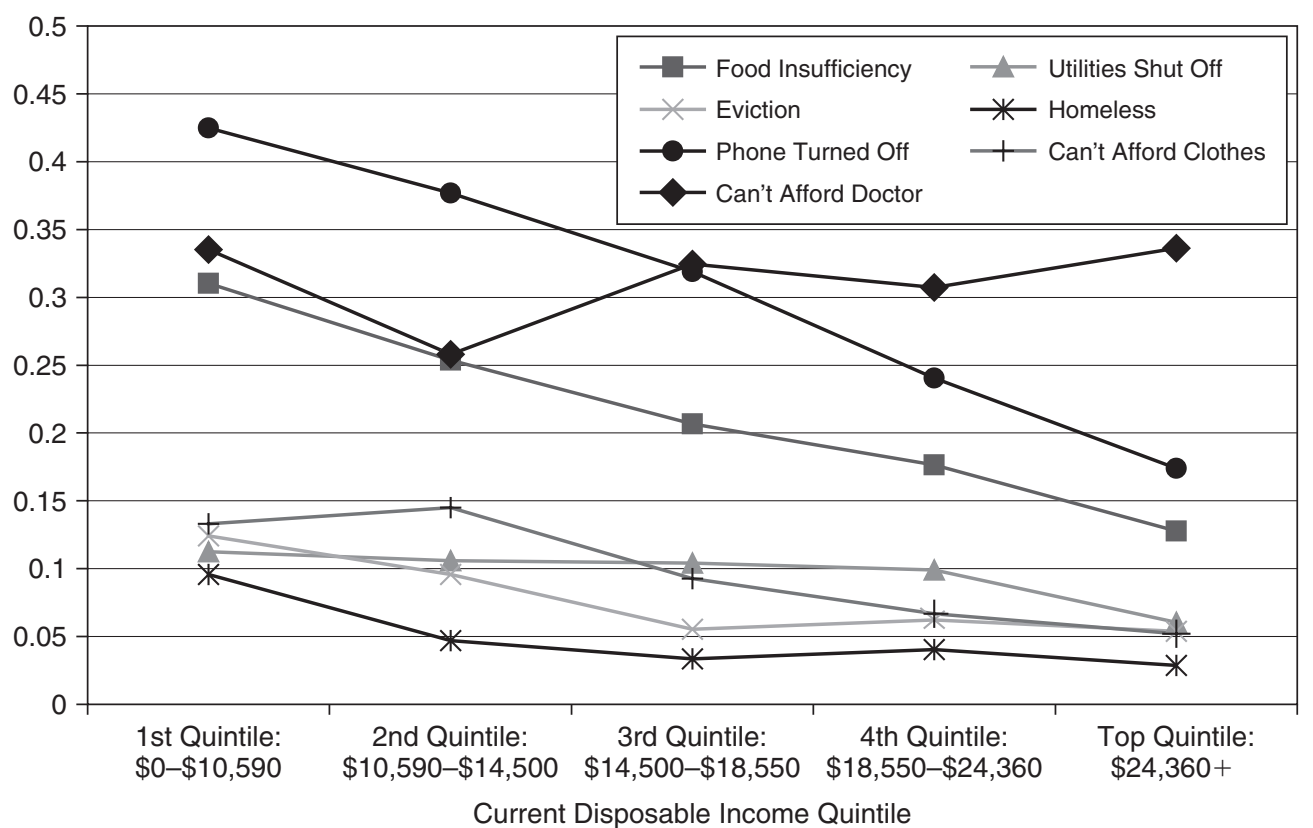

Source: Women's Employment Study (WES), Wave 1-Wave 5, 1997-2003.

Notes: Income values are in constant 2003 dollars.

Figure 2. Fraction experiencing hardships by quintile of current disposable income. 
as in the second quintile (10 vs. 5 percent). A different pattern is evident for the fraction reporting not being able to afford a doctor, which is about the same in the top quintile as in the bottom quintile (35 percent). One reason is that those with higher income are less likely to be eligible for Medicaid and may lack access to private health insurance.

\section{Methodology}

To investigate the relationship between income and material hardship, we estimate pooled cross-section and fixed effects models of the following form:

$$
H_{i t}=\beta_{0}+\beta_{1} Y_{i t}+\beta_{2} \bar{Y}_{i}+\beta_{3} X_{i t}+\gamma_{t}+\varepsilon_{i t}
$$

For most models, $H_{i t}$ is a binary variable indicating whether family $i$ in year $t$ experiences one of the hardships, although we also examine the number of hardships and the incidence of specific hardships. $Y_{i t}$ is the log of disposable income in year $t$ for family $i .{ }^{17} \bar{Y}_{i}$ is the average of log disposable income across all waves of the panel for family $i . X_{i t}$ includes other observable characteristics that may affect hardship.

Previous studies have shown that hardship varies by demographic characteristics and by family types, such as married couples, cohabiting partners, and single parents (Lerman, 2002; Ouellette et al., 2004). Thus, $X_{i t}$ includes indicators for whether the mother is married, whether a cohabiting partner is present, demographic characteristics such as race and the number of children present, and measures of human capital, including indicators for educational attainment and a quadratic in age. We also include indicators for mental health disorders, drug use, and physical health status, which are not available in most surveys.

In some specifications, we analyze the importance of income uncertainty, measured as the variance of log disposable income over the panel, following Carroll and Samwick (1998). We also include measures that reflect credit constraints, such as an indicator for perceived access to credit, defined as whether the respondent could borrow several hundred dollars if needed, and measures of assets, including home ownership, car ownership, and having a checking or savings account. To capture time effects that affect all respondents similarly, such as macroeconomic conditions over the panel, we include year dummies, $\gamma_{t}{ }^{18}$ We estimate models with and without individual fixed effects. In the pooled cross-section models, we correct the standard errors to allow for within-household dependence over time.

\section{EMPIRICAL RESULTS}

\section{Cross-Section Results}

Table 3 presents linear probability model estimates of the relationship between any hardship and contemporaneous disposable income. ${ }^{19}$ The bivariate results in column 1 are consistent with those from Figure 1 -current disposable income is negatively related to hardship. The point estimate indicates that a 10 percent increase in disposable income is associated with a 0.75 percentage point decrease in the probability

\footnotetext{
${ }^{17} \mathrm{Log}$ income is used because the relationship between income and hardship is not likely to be linear; a given dollar change in income is likely to have a different effect on hardship for lower income households than for higher income households.

${ }^{18}$ The coefficients on the year dummies are small and not statistically significant; findings do not change when these dummies are excluded.

${ }^{19}$ Table 3 presents estimates from linear probability models. The results are quite similar for logit and probit models.
} 
Table 3. OLS estimates for disposable income.

Dependent Variable: Any Hardship

Full Sample from the WES

Less-Educated Single Mothers from the 1996 SIPP

\begin{tabular}{|c|c|c|c|c|c|c|}
\hline Sample & (1) & (2) & (3) & (4) & (5) & (6) \\
\hline Log Disposable Income & $\begin{array}{l}-0.075 \\
(0.016) * *\end{array}$ & $\begin{array}{l}-0.030 \\
(0.012) *\end{array}$ & $\begin{array}{c}-0.016 \\
(0.012)\end{array}$ & $\begin{array}{l}-0.076 \\
(0.012) * *\end{array}$ & $\begin{array}{l}-0.032 \\
(0.013) *\end{array}$ & $\begin{array}{c}0.045 \\
(0.025)\end{array}$ \\
\hline $\begin{array}{l}\text { Average Log Disposable } \\
\text { Income }\end{array}$ & & & $\begin{array}{l}-0.111 \\
(0.038) * *\end{array}$ & & & $\begin{array}{l}-0.105 \\
(0.031) * *\end{array}$ \\
\hline Variance of Log & & & -0.020 & & & 0.019 \\
\hline Disposable Income & & & $(0.005)^{* * *}$ & & & $(0.025)$ \\
\hline Age & & $\begin{array}{c}0.007 \\
(0.010)\end{array}$ & $\begin{array}{c}0.007 \\
(0.010)\end{array}$ & & $\begin{array}{c}0.009 \\
(0.007)\end{array}$ & $\begin{array}{l}0.007 \\
(0.007)\end{array}$ \\
\hline Age Squared & & $\begin{array}{c}-0.000 \\
(0.000)\end{array}$ & $\begin{array}{c}-0.000 \\
(0.000)\end{array}$ & & $\begin{array}{c}0.000 \\
(0.000)\end{array}$ & $\begin{array}{c}0.000 \\
(0.000)\end{array}$ \\
\hline No High School Degree & & $\begin{array}{l}0.130 \\
(0.030) * *\end{array}$ & $\begin{array}{l}0.107 \\
(0.031) * *\end{array}$ & & $\begin{array}{l}0.046 \\
(0.017) * *\end{array}$ & $\begin{array}{l}0.037 \\
(0.018) *\end{array}$ \\
\hline High School Grad & & $\begin{array}{l}0.053 \\
(0.024)^{*}\end{array}$ & $\begin{array}{c}0.041 \\
(0.024)\end{array}$ & & & \\
\hline Race $=$ African American & & $\begin{array}{c}-0.049 \\
(0.024) *\end{array}$ & $\begin{array}{c}-0.060 \\
(0.024) *\end{array}$ & & $\begin{array}{c}-0.001 \\
(0.018)\end{array}$ & $\begin{array}{r}-0.007 \\
(0.018)\end{array}$ \\
\hline Number of Children & & $\begin{array}{l}0.020 \\
(0.008) *\end{array}$ & $\begin{array}{c}0.013 \\
(0.009)\end{array}$ & & $\begin{array}{l}0.016 \\
(0.006) *\end{array}$ & $\begin{array}{l}0.014 \\
(0.006) *\end{array}$ \\
\hline Married & & $\begin{array}{r}-0.059 \\
(0.030)\end{array}$ & $\begin{array}{c}-0.053 \\
(0.030)\end{array}$ & & & \\
\hline Cohabiting & & $\begin{array}{r}-0.033 \\
(0.027)\end{array}$ & $\begin{array}{c}-0.028 \\
(0.027)\end{array}$ & & & \\
\hline Poor Health Status & & $\begin{array}{l}0.079 \\
(0.025) * *\end{array}$ & $\begin{array}{l}0.069 \\
(0.025) * *\end{array}$ & & & \\
\hline Mental Health Disorder & & $\begin{array}{l}0.173 \\
(0.022) * *\end{array}$ & $\begin{array}{l}0.176 \\
(0.022) * *\end{array}$ & & $\begin{array}{l}0.103 \\
(0.021)^{* * *}\end{array}$ & $\begin{array}{l}0.102 \\
(0.021)^{* * *}\end{array}$ \\
\hline Illegal Drug Use & & $\begin{array}{l}0.128 \\
(0.028)^{* * *}\end{array}$ & $\begin{array}{l}0.124 \\
(0.028) * *\end{array}$ & & & \\
\hline Own a Car & & $\begin{array}{l}-0.126 \\
(0.027)^{* *}\end{array}$ & $\begin{array}{l}-0.113 \\
(0.027) * *\end{array}$ & & $\begin{array}{l}-0.039 \\
(0.018) *\end{array}$ & $\begin{array}{c}-0.032 \\
(0.018)\end{array}$ \\
\hline Homeowner & & $\begin{array}{l}-0.056 \\
(0.025) *\end{array}$ & $\begin{array}{l}-0.051 \\
(0.025) *\end{array}$ & & $\begin{array}{l}-0.042 \\
(0.018)^{*}\end{array}$ & $\begin{array}{c}-0.037 \\
(0.018) *\end{array}$ \\
\hline Observations & 2,978 & 2,978 & 2,978 & 1,657 & 1,657 & 1,657 \\
\hline
\end{tabular}

Source: WES, 1997-2003, and 1996 Panel of the SIPP, Waves 5-8.

Notes: Columns 2-3 include year fixed effects and the standard errors in parentheses allow for withinhousehold dependence. The hardships included in columns 1-3 are: food insufficiency, utilities shut off, eviction, and homelessness. The hardships included in columns 4-6 are: food insufficiency, utilities shut off, and eviction. * significant at 5\%; ** significant at 1\%. See the Appendix online for more details.

of experiencing any of the four hardships-a decrease of 2.3 percent at the mean. ${ }^{20}$ As controls are added for other observable characteristics, the magnitude of this income coefficient decreases, but remains significant (column 2). After both average disposable income over the panel, our measure of "permanent" income, and the

${ }^{20}$ As discussed earlier, these are not causal estimates. Thus, they should not be used to determine how effective means-tested income transfer programs are at reducing hardship. 
variance of income are included (column 3), the coefficient on current income is no longer significant.

These results suggest that, among families with the same mean and variance of long-run income, a marginal change in current income is not strongly related to material hardship. Holding current income fixed, a 10 percent increase in average income over the panel is associated with a 1.1 percentage point decrease in the probability of experiencing a hardship, a change of 3.4 percent. Estimates for the relationship between the variance of income and hardship are significant, but small (column 3). Excluding the variance of income from these models does not affect other estimates noticeably.

Estimates from a SIPP sample of single mothers with a high school degree or less (columns 4 to 6) are quite similar to the WES estimates, suggesting that the WES results are generalizable to broader populations of disadvantaged families. For example, a 10 percent increase in average income is associated with a 1.1 percent decline in hardship among SIPP respondents (column 6). When we analyze a larger SIPP sample that includes all poor households (tables available on request), we also find that holding long-run income constant, current income is not significantly related to hardships. The estimated coefficient for average income is statistically significant for the poverty sample, but the magnitude is about a third of the size of that reported in column 6 for less-educated single mothers. For the sample of all poor families, an indicator for being a single mother is positive and significantly related to hardship.

The results in Table 3 suggest that observable characteristics are strongly related to hardship. ${ }^{21}$ Women who do not finish high school are significantly more likely to experience a hardship than more educated women; the difference ranges from about 11 to 13 percentage points across WES specifications and about 4 to 5 points in SIPP specifications. Having a mental health disorder increases the probability of experiencing a hardship by about 17 percentage points in the WES and by about 10 points in the SIPP. The probability of experiencing hardship is about 12 percentage points greater for those who report illegal drug use. Respondents who own a car or a house are significantly less likely to experience hardship.

In estimates not reported here, we find that access to credit and having a checking or savings account are significantly related to hardship. The probability of experiencing a hardship is 16.3 percentage points higher for those without access to formal or informal credit. The coefficients on these observables are quite large relative to those on income. In addition, $R^{2} \mathrm{~s}$ from bivariate regressions indicate that many of these characteristics explain more of the variation in hardship than does income. For example, having a mental health disorder explains more than four times as much of the variation in hardship as does current disposable income.

\section{Individual Fixed Effects Results}

The fixed effects models follow Equation (1), but the error term includes an individualspecific, time-invariant component $\left(\delta_{i}\right)$, so that $\varepsilon_{i t}=\delta_{i}+\eta_{i t}$. These fixed effects models control for time-invariant characteristics that might be correlated with both income and hardship. For example, some women may be more resourceful at avoiding hardship than others, and resourcefulness might be correlated with income. In addition, these fixed effects models allow us to examine the relationship

\footnotetext{
${ }^{21}$ Lerman (2002) shows that married couples are less likely to experience hardship than cohabiting couples, after controlling for income, education, and other characteristics. Mayer and Jencks (1989) show that homeownership, the ability to borrow money, and family structure have stronger relationships with hardship than does income.
} 
Table 4. Individual fixed effects estimates.

Dependent Variable: Any Hardship

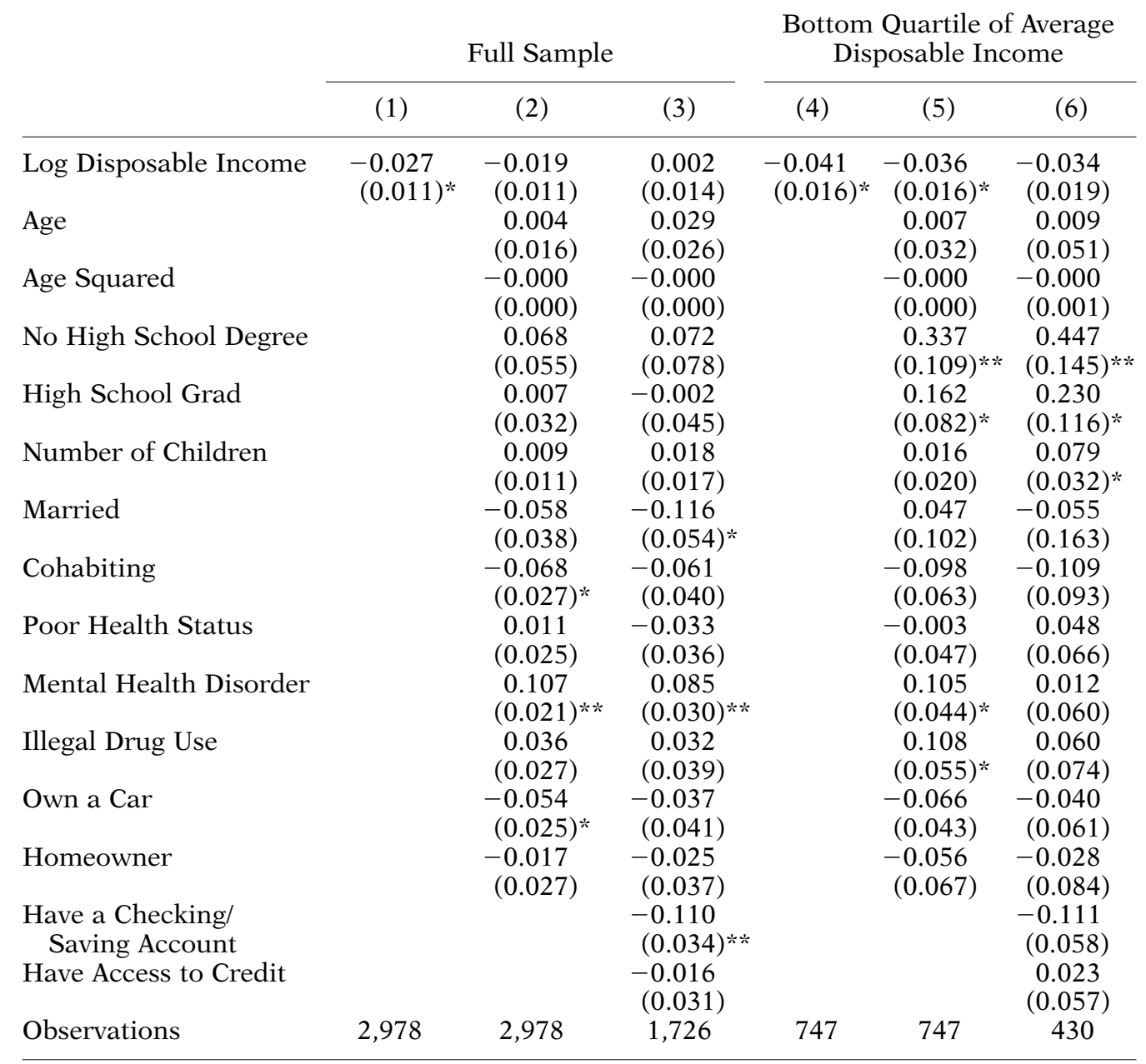

Source: WES 1997-2003.

Notes: Columns 2, 3, 5, and 6 include year fixed effects. ${ }^{*}$ significant at 5\%; ** significant at $1 \%$.

See notes to Table 3 and the Appendix online for more details.

between transitory income-defined as deviations of current income from average income-and hardship. Results from WES specifications are reported in Table 4. We cannot estimate fixed effects models using SIPP data because material hardship is measured at only one point during the panel.

The results do not suggest that material hardship is strongly related to transitory income. ${ }^{22}$ The estimated coefficient for income is small and significant in column 1 when no other covariates are included, small and marginally significant in column 2 , and close to zero and insignificant for specifications that include controls for

${ }^{22}$ These are estimates from linear probability models with individual fixed effects and are qualitatively similar to those from conditional logit models. 
having a checking or savings account and perceived access to credit (column 3). However, the smaller point estimate for income in column 3 appears to result from the loss in observations rather than the inclusion of additional controls. ${ }^{23}$

The right-most columns in Table 4 repeat the specifications of the first three columns, but restrict the sample to WES respondents in the bottom quartile of the distribution of average disposable income to determine if the relationship between transitory income and hardship is stronger for the most disadvantaged women. Although the coefficients on disposable income are somewhat larger in columns 4 to 6 than those for the full sample, they are small. The coefficient in column 5, for example, indicates that a 10 percent increase in transitory income is associated with a decrease in the likelihood of material hardship of 0.36 percentage points, a change of 0.8 percent at the mean.

Some observable characteristics are strongly related to hardship, even after including individual fixed effects. For example, in the full sample, getting married or cohabiting is associated with a reduction in hardship relative to living alone. The likelihood of experiencing hardship is about 10 percentage points higher for women who move from not meeting to meeting the screening criteria for a mental health problem between waves (columns 2, 3, and 5). The probability of hardship is about 11 percentage points lower for those who gain a checking or savings account (columns 3 and 6). ${ }^{24}$

\section{Other Specifications and Checks for Robustness}

To test the sensitivity of these results to our specification of material hardship as a dichotomous variable indicating if the respondent had experienced any one of four hardships, we consider several alternative definitions. In Table 5, we present estimates for nine different measures of hardship. The results for the number of hardships (column 1) are consistent with those reported for any hardship, which is not surprising given that 73 percent of women reporting hardships in the past year report only one of the four main hardships. In the fixed effects model (column 2), the point estimate for disposable income is small and insignificant.

Because indicators for any hardship and the number of hardships treat all hardships equally, we estimate separate models for six specific hardships, including two hardships that were not measured at all five waves: having the phone disconnected and going without proper winter clothing. These results are shown in panel B and panel $\mathrm{C}$ of Table 5. Current income is significant in both the linear probability and the fixed effects models when food insufficiency is analyzed as an individual hardship. A 10 percent increase in current income is associated with a 0.25 percentage point decline in food insufficiency, a 1.1 percent change at the mean. ${ }^{25}$ None of the other coefficients on current income are significant when the other five hardships-having utilities shut off, having phone shut off, can't afford clothing, eviction, and homelessness-are examined separately.

\footnotetext{
${ }^{23}$ For example, estimation of the specification in column 2 for the sample in column 3 yields results similar to those reported for column 3, suggesting that the loss of observations from waves when questions on checking and access to credit were not asked, rather than the inclusion of these variables, causes the point estimate on income to be insignificant.

${ }^{24}$ There is within-individual variation in covariates across waves. The proportion meeting the screening criteria for a mental health disorder decreases between Wave 1 (1997) and Wave 4 (2001), from 0.34 to 0.27 , and increases between Wave 4 and Wave 5 (2003), to 0.31 . The proportion with a checking account increases from 0.60 in Wave 2 (1998) to 0.70 in Wave 5 (2003).

${ }^{25}$ Others have examined the relationship between income and food insufficiency. Using data from the 1991 and 1992 SIPP panels, Gundersen and Gruber (2001) show that food-insufficient households are more likely to have experienced a negative income shock. Corcoran, Heflin, and Siefert (2004), using WES data, find that income has no effect on food insufficiency in fixed effects models.
} 
Table 5. Other measures of hardship.

\begin{tabular}{|c|c|c|c|c|c|c|}
\hline \multirow[t]{2}{*}{ Model } & \multirow{2}{*}{$\begin{array}{c}\text { OLS } \\
(1)\end{array}$} & \multirow{2}{*}{$\begin{array}{l}\mathrm{FE} \\
(2)\end{array}$} & \multirow{2}{*}{$\frac{\text { OLS }}{(3)}$} & \multirow{2}{*}{$\begin{array}{c}\text { FE } \\
(4)\end{array}$} & \multirow{2}{*}{$\frac{\text { OLS }}{(5)}$} & \multirow{2}{*}{$\frac{F E}{(6)}$} \\
\hline & & & & & & \\
\hline $\begin{array}{l}\text { Panel A, Dependent } \\
\text { Variable }\end{array}$ & \multicolumn{2}{|c|}{$\begin{array}{l}\text { \# of Hardships } \\
\text { (out of } 4 \text { ) }\end{array}$} & \multicolumn{2}{|c|}{$\begin{array}{l}\text { \# of Hardships } \\
\text { (out of } 6 \text { ) }\end{array}$} & \multicolumn{2}{|c|}{$\begin{array}{l}\text { Any Hardship } \\
\text { (out of 6) }\end{array}$} \\
\hline Log Disposable Income & $\begin{array}{c}-0.019 \\
(0.020)\end{array}$ & $\begin{array}{l}-0.026 \\
(0.017)\end{array}$ & $\begin{array}{l}-0.030 \\
(0.042)\end{array}$ & $\begin{array}{c}0.002 \\
(0.031)\end{array}$ & $\begin{array}{c}-0.021 \\
(0.016)\end{array}$ & $\begin{array}{c}-0.013 \\
(0.014)\end{array}$ \\
\hline $\begin{array}{l}\text { Average Log Disposable } \\
\text { Income }\end{array}$ & $\begin{array}{l}-0.134 \\
(0.059) *\end{array}$ & & $\begin{array}{l}-0.203 \\
(0.087) *\end{array}$ & & $\begin{array}{l}-0.099 \\
(0.039) *\end{array}$ & \\
\hline Poor Health Status & $\begin{array}{l}0.166 \\
(0.043) * *\end{array}$ & $\begin{array}{c}0.070 \\
(0.039)\end{array}$ & $\begin{array}{l}0.394 \\
(0.079) * *\end{array}$ & $\begin{array}{c}0.127 \\
(0.081)\end{array}$ & $\begin{array}{l}0.138 \\
(0.033) * *\end{array}$ & $\begin{array}{c}0.049 \\
(0.038)\end{array}$ \\
\hline Mental Health Disorder & $\begin{array}{l}0.291 \\
(0.037) * *\end{array}$ & $\begin{array}{l}0.175 \\
(0.033) * *\end{array}$ & $\begin{array}{l}0.453 \\
(0.072) * *\end{array}$ & $\begin{array}{l}0.216 \\
(0.068) * *\end{array}$ & $\begin{array}{l}0.152 \\
(0.028) * *\end{array}$ & $\begin{array}{c}0.065 \\
(0.032)^{*}\end{array}$ \\
\hline Illegal Drug Use & $\begin{array}{l}0.242 \\
(0.047)^{* * *}\end{array}$ & $\begin{array}{c}0.072 \\
(0.042)\end{array}$ & $\begin{array}{l}0.437 \\
(0.091) * *\end{array}$ & $\begin{array}{c}0.159 \\
(0.087)\end{array}$ & $\begin{array}{l}0.140 \\
(0.036) * *\end{array}$ & $\begin{array}{c}0.041 \\
(0.041)\end{array}$ \\
\hline Observations & 2,978 & 2,978 & 1,726 & 1,726 & 1,726 & 1,726 \\
\hline \multicolumn{5}{|l|}{$\begin{array}{l}\text { Panel B, Dependent } \\
\text { Variable } \\
\end{array}$} & \multicolumn{2}{|c|}{ Phone Shut Off } \\
\hline Log Disposable Income & $\begin{array}{l}-0.025 \\
(0.012)^{*}\end{array}$ & $\begin{array}{l}-0.027 \\
(0.010) * *\end{array}$ & $\begin{array}{c}0.003 \\
(0.010)\end{array}$ & $\begin{array}{c}0.001 \\
(0.008)\end{array}$ & $\begin{array}{r}-0.025 \\
(0.013)\end{array}$ & $\begin{array}{c}-0.021 \\
(0.014)\end{array}$ \\
\hline $\begin{array}{l}\text { Average Log Disposable } \\
\text { Income }\end{array}$ & $\begin{array}{c}-0.048 \\
(0.029)\end{array}$ & & $\begin{array}{l}-0.035 \\
(0.023)\end{array}$ & & $\begin{array}{l}-0.084 \\
(0.034) *\end{array}$ & \\
\hline Poor Health Status & $\begin{array}{l}0.083 \\
(0.023) * *\end{array}$ & $\begin{array}{c}0.035 \\
(0.022)\end{array}$ & $\begin{array}{c}0.017 \\
(0.016)\end{array}$ & $\begin{array}{c}-0.004 \\
(0.018)\end{array}$ & $\begin{array}{l}0.133 \\
(0.030) * *\end{array}$ & $\begin{array}{l}0.100 \\
(0.038) * *\end{array}$ \\
\hline Mental Health Disorder & $\begin{array}{l}0.141 \\
(0.021)^{* * *}\end{array}$ & $\begin{array}{l}0.087 \\
(0.019) * *\end{array}$ & $\begin{array}{l}0.054 \\
(0.014) * *\end{array}$ & $\begin{array}{c}0.030 \\
(0.015) *\end{array}$ & $\begin{array}{l}0.093 \\
(0.026) * *\end{array}$ & $\begin{array}{c}0.059 \\
(0.032)\end{array}$ \\
\hline Illegal Drug Use & $\begin{array}{l}0.092 \\
(0.026) * *\end{array}$ & $\begin{array}{c}0.029 \\
(0.024)\end{array}$ & $\begin{array}{l}0.047 \\
(0.018)^{* * *}\end{array}$ & $\begin{array}{c}0.023 \\
(0.020)\end{array}$ & $\begin{array}{l}0.150 \\
(0.034) * *\end{array}$ & $\begin{array}{c}0.092 \\
(0.041) *\end{array}$ \\
\hline Observations & 2,978 & 2,978 & 2,978 & 2,978 & 1,726 & 1,726 \\
\hline
\end{tabular}

Panel C, Dependent

Variable Can't Afford Clothing Eviction Homelessness

\begin{tabular}{lcccccc}
\hline Log Disposable Income & 0.014 & 0.012 & 0.004 & 0.002 & -0.001 & -0.002 \\
& $(0.011)$ & $(0.009)$ & $(0.007)$ & $(0.007)$ & $(0.007)$ & $(0.006)$ \\
Average Log Disposable & -0.024 & & -0.029 & & -0.023 & \\
Income & $(0.026)$ & & $(0.017)$ & & $(0.015)$ & \\
Poor Health Status & 0.092 & 0.039 & 0.032 & 0.013 & 0.033 & 0.025 \\
& $(0.024) * *$ & $(0.023)$ & $(0.014) *$ & $(0.016)$ & $(0.012)^{* *}$ & $(0.013)$ \\
Mental Health Disorder & 0.069 & -0.002 & 0.032 & 0.008 & 0.065 & 0.050 \\
& $(0.019) * *$ & $(0.019)$ & $(0.012) * *$ & $(0.014)$ & $(0.012)^{* *}$ & $(0.011)^{* * *}$ \\
Illegal Drug Use & 0.016 & 0.008 & 0.066 & 0.013 & 0.037 & 0.007 \\
& $(0.024)$ & $(0.024)$ & $(0.017) * *$ & $(0.018)$ & $(0.014)^{* *}$ & $(0.014)$ \\
Observations & 1,726 & 1,726 & 2,978 & 2,978 & 2,978 & 2,978
\end{tabular}

Source: WES 1997-2003.

Notes: OLS models also include the covariates listed in Table 3, column 3. Fixed effects (FE) models also include the covariates listed in Table 4, column 2. Homeownership is not included when Homelessness is the dependent variable. Phone Shut Off and Can't Afford Clothing are not available in waves 1 and 2. See notes to Table 4. 
In most cases, exposure to hardship is greater for those who meet the diagnostic screening criteria for a mental health disorder in both the linear probability and the fixed effects models. Illegal drug use is significant in eight of nine linear probability models, but is significant in only one fixed effects model, the case of having the phone shut off.

In results not reported here (available on request), we examine other income measures. We find that the relationship between annual money income, the definition used for the official poverty statistics, and hardship is smaller than that between annual disposable income and hardship. This suggests that comprehensive income measures are more appropriate for predicting which households face the greatest risk of hardship because resources not included in pre-tax money income, such as the Earned Income Tax Credit (EITC) or food stamps, increase consumption.

To address concerns that surveys measure income with error, especially for recipients of public transfer income (Bound, Brown, \& Mathiowetz, 2001; Meyer \& Sullivan 2003, 2006; Roemer, 2000), we construct an imputed income measure using administrative records for TANF and food stamps. When administrative records rather than respondent reports are used, the results are very similar to those in Tables 3 through 5, which is not surprising, given that underreporting of TANF and food stamps is small among WES respondents. Nevertheless, attenuation bias may still affect our estimates if income sources other than public transfers are subject to classical measurement error.

We also investigate the sensitivity of our results to the timing of reported income and hardship. This temporal ordering is a potential concern because long-run income is measured as the average over several years that follow the reference period for hardship for some respondents (for example, those in Wave 1), but as the average over several years before the reference period for hardship for other respondents (for example, those in Wave 5). We reestimated the models reported in Table 3 for different subsamples and found that the coefficients on long-run income are not sensitive to this difference in temporal ordering. For example, the results for a subsample that excludes Wave 1 observations do not differ noticeably from the results for a subsample that excludes Wave 5 observations.

Temporal ordering is also a potential concern for estimates of current and transitory income because the WES reference period for current income is the month before the survey, whereas the reference period for hardships is the 12 months or more before the survey. In addition, income need not have a contemporaneous effect on hardship. For example, a transitory shortfall in income may cause a woman to fall behind in rent in the current period, leading to her eviction in a later period. We estimate several alternative specifications to address this issue (results available from the authors). Using a measure of self-reported annual income for the previous calendar year yields results similar to those reported in Tables 3 to 5, which are based on annualized monthly income. In the SIPP, we examine annual income for the reference period spanning 5 to 17 months before the interview that asks about hardship; these results are also consistent with those from the WES, as shown in Table 3. Moreover, SIPP results using current income from the year after the reference period on hardship do not differ noticeably from those in Table 3.

Finally, we estimated a model using reported hardships at wave $t$ but all covariates from wave $t-1$. The pooled cross-section results are very similar to those reported in Table 3. For the fixed effects estimates, the coefficient on transitory income is small and positive, and most of the other covariates are not significant. We argue that contemporaneous covariates are more appropriate because in some cases the reference period for period $t-1$ income could be as much as 2 years before the hardship. This long lag could be problematic for fixed effects models if the effect of transitory income shocks is not persistent. 


\section{DISCUSSION}

In cross-section models that controlled for average income over the 6-year WES panel, we found that current annual income is not strongly related to most measures of hardship. In contrast, average income and observable factors such as mental health are significantly related to hardship. These findings have important policy implications for social programs designed to target benefits at those facing the greatest risk of hardship. The significant association between hardships and mental health problems across many specifications, including fixed effects models, suggests that measures of mental health might serve as a proxy for being at high risk of material hardship.

Our fixed effects results also indicated that the relationship between changes in transitory income and changes in material hardship is weak (except for the relationship with food insufficiency), consistent with previous research (Mayer, 1997). This finding is consistent with the permanent income hypothesis, which suggests that some families may avoid hardships by borrowing or dissaving when income is temporarily low. However, because studies of low-income single mothers find that most lack sufficient liquidity to buffer against even modest income shortfalls (Edin \& Lein, 1997; Shapiro \& Wolff, 2001; Meyer \& Sullivan, 2003; Sullivan, 2006), WES respondents are likely to face liquidity constraints. Those with a checking or savings account (about two-thirds of respondents) are significantly less likely to experience hardship, even after controlling for individual fixed effects. In addition, only about one-quarter have a credit card.

Ethnographic research provides a plausible explanation for the weak relationship between current income and hardship. Edin and Lein (1997) show that reported income accounts for only about 60 percent of total resources of welfare-reliant single mothers, with the remainder accounted for by unreported "survival strategies," such as informal or illegal work, purchasing stolen goods at a discount, or through in-kind transfers from family, friends, or partners.

In a measurement model, one could specify the resources necessary to avoid material hardship as having two components: primary income sources $(Y)$ that are reported on surveys and informal sources $(\lambda)$ that are typically not reported. Edin and Lein (1997) conclude that $\lambda$ is large, particularly for welfare-reliant single mothers. Moreover, if families with little income from formal sources, such as earnings or government transfers, are more likely to have informal resources, then $\lambda$ and $Y$ will be negatively correlated. Evidence from the WES supports this hypothesis. For example, regressions of receiving help from charity on disposable income and other demographic characteristics indicate that those with higher current income are less likely to seek help from charity. If $\lambda$ and $Y$ are negatively correlated, then estimates of the effect of current $Y$ on material hardship are likely to be small even in fixed effects models.

Our results have implications for measuring the well-being of the poor in surveys. On the one hand, if measurement error from questions regarding primary income sources (such as labor market earnings or public transfers) is important, then surveys could include more probes to improve the accuracy of income reports. On the other hand, if unmeasured informal resources account for the weak relationship between current income and hardship, then surveys must do a better job of measuring informal sources of support.

\section{CONCLUSIONS}

Hardship decreases monotonically across quintiles of the income distribution for several income measures in our sample of current and former welfare recipients. 
After conditioning on average disposable income over the panel, current disposable income is significantly related only to food insufficiency and not to other measures of hardship. Average disposable income is more often significantly related to hardship. For example, a 10 percent increase in average income is associated with a 1.1 percentage point decrease in the likelihood of experiencing any of four hardshipsa drop of about 3.4 percent at the mean. Thus, for a minimum wage worker, the receipt of the maximum EITC (a 40 percent earnings subsidy) on a permanent basis would be associated with a 16 percent reduction in the likelihood of hardship. Analyses for a sample of less-educated single mothers from the SIPP also indicate a stronger relationship between average income and hardship. Although these estimates should not be interpreted as causal, they do have important policy implications. Our results suggest that social programs might better target benefits at those facing the greatest risk of hardship by considering factors associated with low longrun income.

Models that include individual fixed effects indicate that the relationship between transitory income and hardship is weak, which is consistent with ethnographic research suggesting that informal, unmeasured resources help disadvantaged families make ends meet. Other observable factors, such as meeting the diagnostic screening criteria for a mental health disorder and having a checking or savings account, are strongly associated with the risk of hardship. A woman meeting the screening criteria for a mental health disorder is more than 10 percentage points more likely to experience material hardship than others.

Current income is correlated with many observable and unobservable characteristics that are related to hardship. Because current income is relatively easy to measure, it provides a useful, albeit imperfect, indicator of risk of hardship, and it is a practical, single measure to use for eligibility for transfer programs that aim to prevent material hardship. However, welfare agencies, training programs, and service providers should consider gathering additional information on personal characteristics, including long-run income or mental health. For example, available survey instruments that screen for mental health disorders could be used to predict which program participants are at high risk of hardship. ${ }^{26}$ These participants could then be referred to appropriate service and treatment programs.

JAMES X. SULLIVAN is an Assistant Professor in the Department of Economics and Econometrics at the University of Notre Dame.

LESLEY TURNER is a graduate student in the Department of Economics at Columbia University.

SHELDON DANZIGER is Henry J. Meyer Distinguished University Professor of Public Policy, Gerald R. Ford School of Public Policy, and Co-Director, National Poverty Center, University of Michigan.

\section{ACKNOWLEDGMENTS}

The Women's Employment Study was supported by grants from the Charles Stewart Mott, the Joyce, and the John D. and Catherine T. MacArthur Foundations and the National Institute of Mental Health (R24-MH51363). The authors thank Rebecca Blank, Steven Haider, and three anonymous referees for helpful comments.

\footnotetext{
${ }^{26}$ Our suggestion to screen program participants who are most likely to experience material hardship is similar to Bane and Ellwood (1983), which suggests that program resources should be targeted on welfare recipients who have the greatest probability of becoming long-term recipients.
} 


\section{REFERENCES}

Bane, M. J., \& Ellwood, D. (1983). The dynamics of dependence: The routes to self-sufficiency. Prepared for the Office of Planning and Evaluation, U.S. Department of Health and Human Services.

Beverly, S. G. (1999). Economic poverty reconsidered: Material hardship and income-poverty in the United States. St. Louis, MO: Washington University.

Beverly, S. G. (2000). Using measures of material hardship to assess well-being. Focus, 21, 65-69.

Beverly, S. G. (2001). Measures of material hardship: Rationale and recommendations. Journal of Poverty, 5, 23-41.

Bhattacharya, J., Currie, J., \& Haider, S. (2004). Poverty, food insecurity, and nutritional outcomes in children and adults. Journal of Health Economics, 23, 839-862.

Blau, D. (1999). The effect of income on child development. Review of Economics and Statistics, 81, 261-276.

Bound, J., Brown, C., \& Mathiowetz, N. (2001). Measurement error in survey data. In Heckman, J., \& Leamer, E. (Eds.), Handbook of econometrics, Volume 5 (pp. 3705-3843). Amsterdam: Elsevier.

Boushey, H., \& Gundersen, B. (2001). When work just isn't enough: Measuring hardships faced by families after moving from welfare to work. Economic Policy Institute. Retrieved May 24, 2007, from http://www.epinet.org/briefingpapers/hardshipsbp.pdf.

Cadena, B., \& Pape, A. (2006). The extent and consequences of attrition in the Women's Employment Study. University of Michigan, Program on Poverty and Social Welfare Policy Working Paper. Retrieved May 24, 2007, from http://www.fordschool.umich.edu/ research/poverty/pdf/WES_Attrition-06.pdf.

Carroll, C. D., \& Samwick, A. A. (1998). How important is precautionary saving? Review of Economics and Statistics, 80, 410-419.

Citro, C. F., \& Michael, R. T. (Eds.). (1995). Measuring poverty: A new approach. Washington, DC: National Academy Press.

Corcoran, M., Heflin, C. M., \& Siefert, K. (2004). Work trajectories, income changes and food insufficiency in the welfare population. University of Michigan, Program on Poverty and Social Welfare Policy Working Paper. Retrieved May 24, 2007, from http://www.ford school.umich.edu/research/poverty/pdf/Work\%20Trajectories, $\% 20$ Income $\% 20$ Changes $\%$ 20and\%20Food\%20Insufficiency.pdf.

Dahl, G., \& Lochner, L. (2005). The impact of family income on child achievement. NBER Working Paper No. w11279. Cambridge, MA: National Bureau of Economic Research. Retrieved May 24, 2007, from http://papers.nber.org/papers/w11279.pdf.

Edin, K., \& Lein, L. (1997). Making ends meet: How single mothers survive welfare and lowwage work. New York, NY: Russell Sage Foundation.

Eisenhower, D., Mathiowetz, N., \& Morganstein, D. (1991). Recall error: Sources and bias reduction techniques. In Biemer, P., Groves, R. M., Lyberg, L. E., Mathiowetz, N. E., \& Sudman, S. (Eds.), Measurement errors in surveys. New York, NY: John Wiley.

Federman, M., Garner, T. I., Short, K., Cutter IV, W. B., Kiely, J., Levine, D., McDough, D., \& McMillen, M. (1996). What does it mean to be poor in America? Monthly Labor Review, 119, 3-17.

Feenberg, D. R., \& Coutts, E. (1993). An introduction to the TAXSIM Model. Journal of Policy Analysis and Management, 12, 189-194.

Groves, R. M. (1989). Survey errors and survey costs. New York, NY: Wiley.

Gundersen, C., \& Gruber, J. (2001). The dynamic determinants of food insufficiency. In Andrews, M. S., \& Prell, M. A. (Eds.), Second food security measurement and research conference, Volume II: Papers 2001. Washington, DC: U.S. Department of Agriculture, Economic Research Service. 
Iceland, J., \& Bauman, K. (2007). Income poverty and material hardship. The Journal of Socio-Economics, 36, 376-396.

Lerman, R. I. (2002). Impacts of marital status and parental presence on the material hardship of families with children. Washington, DC: Urban Institute. Retrieved May 24, 2007, from http://www.urban.org/url.cfm?ID=410538.

Mayer, S. E. (1997). What money can't buy: Family income and children's life chances. Cambridge, MA: Harvard University Press.

Mayer, S. E., \& Jencks, C. (1989). Poverty and the distribution of material hardship. The Journal of Human Resources, 24, 88-114.

Meyer, B. D., \& Sullivan, J. X. (2003). Measuring the well-being of the poor using income and consumption. Journal of Human Resources, 38, 1180-1220.

Meyer, B. D., \& Sullivan, J. X. (2006). Consumption, income, and material well-being after welfare reform. NBER Working Paper No. w11976. Cambridge, MA: National Bureau of Economic Research. Retrieved May 24, 2007, from http://papers.nber.org/papers/w11976.pdf.

Ouellette, T., Burstein, N., Long, D., \& Beecroft, E. (2004). Measures of material hardship final report. Prepared for U.S. Department of Health and Human Services, ASPE. Retrieved May 24, 2007, from http://aspe.hhs.gov/hsp/material-hardship04/report.pdf.

Rector, R., Johnson, K., \& Youssef, S. (1999). The extent of material hardship and poverty in the United States. Review of Social Economy, 57, 351-385.

Roemer, M. I. (2000). Assessing the quality of the March Current Population Survey and the Survey of Income and Program Participation Income estimates, 1990-1996. Staff Papers on Income, Housing and Household Economic Statistics Division. Washington, DC: U.S. Census Bureau.

Seefeldt, K. S., \& Orzol, S. M. (2005). Watching the clock tick: Factors associated with TANF accumulation. Social Work Research, 29, 215-229.

Shapiro, T., \& Wolff, E. (Eds.). (2001). Assets for the poor: The benefits of spreading asset ownership. New York, NY: Russell Sage Press.

Sullivan, J. X. (2006). Welfare reform, saving, and vehicle ownership for the poor: Do asset tests and vehicle exemptions matter? Journal of Human Resources, 41, 72-105.

Short, K. S. (2005). Material and financial hardship and income-based poverty measures in the USA. Journal of Social Policy, 34, 21-38.

Turner, L. J., Danziger, S., \& Seefeldt, K. S. (2006). Failing the transition from welfare to work: Women disconnected from work, welfare, and other sources of economic support. Social Science Quarterly, 87, 227-249.

United States Senate. (2004). Food Stamp Act of 1977. PL 88-525. Retrieved May 24, 2007, from http://agriculture.senate.gov/Legislation/Compilations/FNS/FSA77.pdf. 


\section{APPENDIX: VARIABLE DEFINITIONS AND NOTES}

Measures of Income: All income measures are adjusted for inflation using the CPI-U and reported in constant 2003 dollars. We use the equivalence scale recommended by Citro and Michael (1995)_-(number of adults + number of children*0.7 $)^{0.7}$-and standardize this scale to represent a family with one adult and two children.

Disposable Income: WES: This annualized measure is defined as 12 times the respondent's self-reported income for the month before the interview from the following sources: own earnings, earnings of other household members, cash welfare benefits (TANF), food stamps, child support, Social Security Disability Insurance income, Supplemental Security Income (SSI), unemployment insurance/workers' compensation, transfers from friends and family, and income from other sources, minus federal and state income and payroll taxes and plus tax credits, such as the earned income tax credit and the state homestead tax credit (calculated using NBER's TAXSIM [Feenberg \& Coutts, 1993] and annualized money income). SIPP: This annual measure is calculated using income from Waves 5 to 7 of the 1996 SIPP, which span the 12 months before Wave 8 when hardships were reported. The components of this measure match those of the WES. Again, TAXSIM is used to calculate taxes and credits.

Average Income: WES: Average income is calculated as the average of current income over all waves of the panel for each respondent. Because only respondents who participated in at least three waves are included, the average is over 3 to 5 waves. SIPP: The average is taken over the 4 years of the panel.

Hardships: WES: For the first interview, all hardships were measured over the 12 months before the interview. In Waves 2 through 5, hardships were measured over the period between interviews. SIPP: All hardships are measured at Wave 8 . Depending on the hardship, the reference period is either 4 months before or a year before the survey month.

Food Insufficiency: WES: A respondent is coded as experiencing food insufficiency if she responds "sometimes not enough" or "often not enough" to the question "Which of these statements best describes the food eaten in your household in the last 12 months-enough to eat, sometimes not enough to eat, or often not enough to eat?" SIPP: This definition follows that of the WES very closely, although the reference period is the previous 4 months.

Utilities Shut Off: WES: "Has your gas or electricity been turned off at any time in the last year/since [the last interview date] because you couldn't afford to pay the bill?" SIPP: "In the past 12 months did the gas or electric company turn off service, or the oil company not deliver oil?"

Evicted: WES: "Have you been evicted in the last year/since [the last interview date]?" SIPP: "Was there any time in the past 12 months when ... were evicted from your home or apartment for not paying the rent or mortgage?"

Homeless: WES: "Have you ever been homeless in the last year/since [the last interview date]?"

Can't Afford Doctor: WES: "Was there any time since the last interview date that you needed to see a doctor or dentist but could not afford to go?" Respondents were only asked this question in Waves 3 through 5.

Phone Turned Off: WES: "Has your phone been disconnected, or have you gone without a phone at any time since the last interview date because you could not afford to pay the bill?" Respondents were only asked this question in Waves 3 through 5.

Can't Afford Clothing: WES: "Did you or your children go without proper winter clothing at any time since the last interview date because you could not afford it?" Respondents were only asked this question in Waves 3 through 5. 
Mental Health: WES: A respondent is coded as having a mental health disorder if she meets the diagnostic screening criteria for major depression, alcohol dependence, or posttraumatic stress disorder in the 12 months before the interview. The measurement and scoring of disorders is based on criteria from the revised third edition of the American Psychiatric Association's Diagnostic and Statistical Manual of Mental Disorders (DSM-III-R). SIPP: A respondent is coded as having a mental health disorder if she responds affirmatively to questions about whether she is frequently depressed or anxious, has a lot of trouble coping with day-to-day stresses, or has other mental or emotional conditions.

Illegal Drug Use: WES: This indicator is equal to one if the respondent reports any illegal drug use in the 12 months before the interview.

Poor Health Status: WES: Having poor health status is defined by having an agespecific physical limitation and self reported fair/poor health.

Access to Credit: WES: We consider a respondent to have access to credit if she answers "yes possibly," "yes probably," or "yes definitely" to the question "Is there someone you could turn to if you needed to borrow several hundred dollars for an emergency?" This question is not asked in the third wave of WES. 